\title{
Coral disease dynamics in the central Philippines
}

\author{
Longin T. Kaczmarsky ${ }^{1,2, *}$ \\ ${ }^{1}$ Silliman University Marine Laboratory, Dumaguete City, Negros Oriental, 6200 Philippines \\ ${ }^{2}$ Present address: Department of Biological Sciences, Florida International University, 11200 SW 8th St., Miami, \\ Florida 33199, USA
}

\begin{abstract}
Limited quantitative research has been conducted on coral disease in the Philippines and baseline data are much needed. Field surveys for prevalence and distribution patterns were conducted from November 2002 to August 2003. Sites included the islands of Negros, Cebu, Siquijor, Panglao, Olango, Sumilon, Bantayan, Pescador, Balicassag and Palawan. In 154 belt transects, 10026 Porites colonies were examined at 28 sites covering $3080 \mathrm{~m}^{2}$. Two syndromes, Porites ulcerative white spot (PUWS) and coral tumors, occurred at high prevalence. Tumors as high as 39.1\% occurred among massive Porites, and PUWS was as high as $53.7 \%$ among massive and branching Porites. In 8 mo, 116 tagged colonies showed slow progression and low mortality. Along a $41 \mathrm{~km}$ human impact gradient centered on Dumaguete City (Negros), 15 sites were examined. Correlation analyses linked higher disease prevalence to anthropogenic influence (Spearman's rank correlation coefficient $\left[r_{S}\right]=$ $-0.54, p=0.04$ for tumors and $r_{S}=-0.69, p=0.005$ for PUWS). In most sites disease prevalence was lower than in the sites near Dumaguete. High PUWS prevalence near uninhabited Sumilon Island appeared to be linked to the highly diseased reefs near Dumaguete City due to transmission of disease along a cross-shelf front formed between the Tañon Strait and Bohol Sea. Other observations included 12 potential new host species for PUWS (4 new genera and 1 octocorallia) and 5 likely new hosts for black band disease (BBD) in the Philippines, and a relatively high prevalence (7.8\%) of BBD in 1 site in western Palawan.
\end{abstract}

KEY WORDS: Coral disease · Philippines $\cdot$ Coral tumors · Indo-Pacific $\cdot$ Gradient study $\cdot$ Porites · Disease prevalence $\cdot$ Porites ulcerative white spot syndrome

\section{INTRODUCTION}

It has been estimated that coral reefs are in decline throughout the world and that coral disease is a significant factor contributing to this decline (Wilkinson 2002, Rosenberg \& Loya 2004). However, few quantitative studies on the role played by coral disease in this decline have been conducted on reefs on a worldwide basis (Sutherland et al. 2004). While it is believed that the number of species affected by disease in the IndoPacific is proportionately much lower than the Caribbean (Sutherland et al. 2004), almost nothing quantitative is known of coral disease prevalence, distribution patterns or impact on many Indo-Pacific reefs (Raymundo et al. 2003). It is widely thought that coral disease is not a major threat to Indo-Pacific reefs. How- ever, the results of recent quantitative research suggest otherwise (Kaczmarsky 2004).

A region not investigated to any great extent is the Philippines. The earliest reports of coral disease in the Philippines were of black band disease (BBD) and white band disease (WBD) in 1981 (Antonius 1985a). Early observations of WBD in the Indo-Pacific are now believed, however, to be white plague-like diseases, not WBD (Sutherland et al. 2004). Throughout the IndoPacific, 45 species are known to be susceptible to BBD (Sutherland et al. 2004). BBD is a worldwide disease of corals and is characterized by a black mat, a few millimeters to centimeters wide that forms a dark ring or band and separates apparently healthy coral tissue from freshly exposed coral skeleton. It migrates across coral colonies and completely degrades coral tissue. 
The infecting agent is a synergistic consortium of photosynthetic and non-photosynthetic bacteria. In 1996, Porites ulcerative white spot syndrome (PUWS) was first observed infecting corals in the Philippines and in 1998 it was observed in 8 of 10 central Philippine sites (Raymundo et al. 2003). It affects Philippine reefs but is not documented elsewhere. Its cause remains unknown. PUWS is characterized by discrete, bleached, round foci, 3 to $5 \mathrm{~mm}$ in diameter, that may result in ulcerations that coalesce and cause tissue loss and colony mortality (Raymundo et al. 2003). Other Indo-Pacific diseases not previously observed in the Philippines include, but are not limited to, Porites pink-line syndrome (Ravindran \& Raghukumar 2002) and coral tumors (Coles \& Seapy 1998, Hunter 1999, Yamashiro et al. 2000, Gateño et al. 2003). Coral reef bleaching in the Philippines has caused acute losses of coral cover (Raymundo \& Maypa 2002, Wilkinson 2002).

The work reported here is the result of the first comprehensive, quantitative examination of coral disease in the Philippines. Several aspects of coral disease etiology were examined during the course of this study. Reported here are the results of (1) an environmental gradient study to investigate a potential link between human activity and disease, (2) a region-wide disease prevalence and severity study to gather baseline data, (3) a disease progression study to characterize the individual diseases, and (4) a disease incidence study to characterize temporal variability. Also discussed are disease processes, coral species affected, and potential environmental factors that might be contributing to disease patterns.

The 2 syndromes, PUWS and coral tumors, occurred at high prevalence in this study. The tumors (a type of 'skeletal anomaly', Sutherland et al. 2004) were pale areas of tissue with an inconsistent morphology ranging from round, raised areas of enlarged corallites with distinct demarcation lines between unaffected and diseased tissue to very irregularly shaped depressed areas of white and pink tissue and no distinct lines of separation. In some cases they caused tissue loss and mortality. Tumor prevalence was as high as $39.1 \%$ among massive Porites. PUWS was as high as $53.7 \%$ among massive and branching Porites. Correlation analyses linked higher disease prevalence to anthropogenic influence. High PUWS prevalence near uninhabited Sumilon Island appeared to be linked to the highly diseased reefs near Dumaguete City with disease transmission probably occurring along a crossshelf front formed between the Tañon Strait and Bohol Sea. Other observations included 12 potentially new host species for PUWS (4 new genera and 1 octocorallia), 5 likely new hosts for black band disease (BBD) in the Philippines, and a relatively high prevalence $(7.8 \%)$ of BBD in 1 site in western Palawan.

\section{MATERIALS AND METHODS}

Study sites. Several studies related to coral disease were conducted between November 2002 and August 2003 in 28 fringing reefs sites (at a depth of 1 to $3 \mathrm{~m}$ ) in the central Philippines. Data gathered from these investigations included the prevalence, severity, incidence, and progression of coral disease. Much of the work was conducted on reefs off southeast Negros Island near Silliman University Marine Laboratory (SUML), Dumaguete City (capital of southern Negros Island). Other survey sites were off the islands of Cebu, Siquijor, Panglao, Olango, Sumilon, Bantayan, Pescador, Balicassag and Palawan (Fig. 1).

Field survey methods. Reconnaissance surveys: Before transect surveys were conducted, reconnaissance surveys in November and December of 2002 revealed 2 widespread coral syndromes, PUWS and tumors, near SUML. Both mainly affected the genus Porites. It was observed then that few taxa in this highly diverse region were diseased other than Porites, which is often dominant, thus the surveys focused on the affected species in the genus Porites. Tumors affected almost exclusively massive Porites species. PUWS affected massive and branching species of Porites.

Transect methodology: Study sites were haphazardly selected and locations recorded with GPS using a Magellan 315. In each site, 6 transects $(10 \times 2 \mathrm{~m})$ were surveyed for prevalence and severity of PUWS and coral tumors. Other coral diseases and syndromes present at a much lower rate were also noted. Sites were selected after swim surveys of near-shore habitat revealed: (1) an abundance of Porites and (2) the locations of stretches of sand, grass, algae, and large monotypic stands of acroporids and montiporids. The latter areas were avoided. Based on estimates of the Porites population in reconnaissance surveys, it was determined that 6 transects would yield a minimum of 100 colonies, thus providing a fairly accurate representation of disease prevalence. Disease prevalence for each site was based upon pooling colonies from the 6 transects. The first transect in each site began from the point at which a blindly tossed marker came to rest, and followed the contour of the shoreline. Subsequent transects were 5 mapart, either in a seaward direction if the reef was wide or, if not, in a line parallel to the shore. For all sites, every colony $\geq 2 \mathrm{~cm}$ (max. width) of the species under study was counted. In each site, prevalence was calculated as number of diseased colonies divided by total number of colonies (diseased and unaffected), all 6 transects combined. For diseased colonies in all sites, PUWS infections were assigned an approximate degree of severity based on the approximate number of spots per colony as follows. A 'light' 


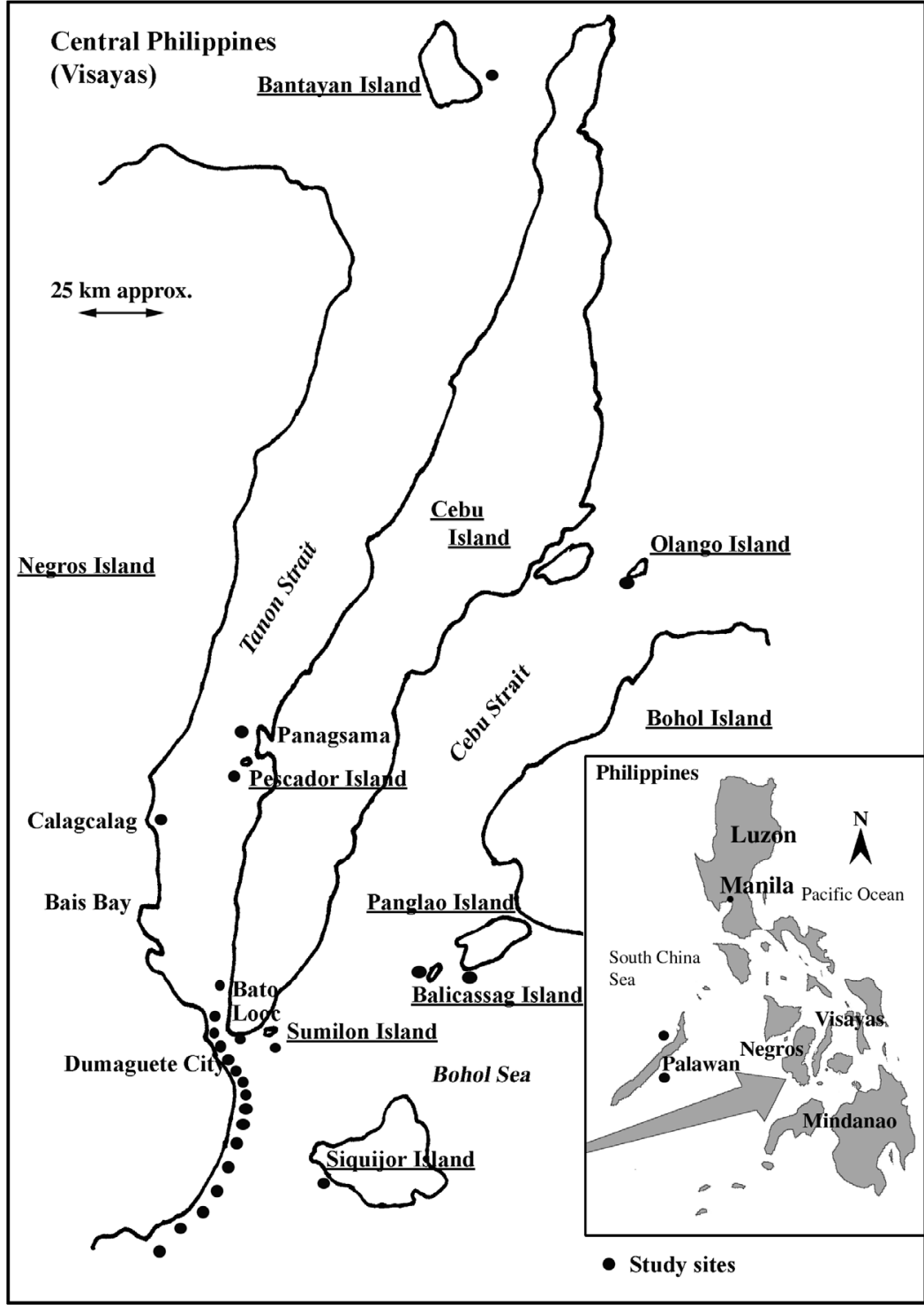

Fig. 1. Central Philippines. Fifteen reef sites surveyed for coral disease along an environmental gradient (sites on the coast in the vicinity of Dumaguete City) and 13 other isolated disease survey sites (see also inset) infection was considered to be 5 to 10 spots, 'moderate' 11 to 50, and 'heavy' more than 50. Colonies having coalesced lesions with recent tissue mortality were also designated as having 'heavy' infection. To be cautious, the presence of less than 5 spots was not counted as this may be difficult to distinguish from the occasionally observed small isolated bleached spots or lesions caused by sediment, fish feces, or bio-eroders. For colonies with tumors, tumor-affected surface area was visually approximated as a percentage of total surface area (e.g. $5 \%, 10 \%$ etc.). Because of very irregular tumor shapes (see Fig. 6A,B) and the high number of PUWS spots on many colonies, quantification of progression was limited to the categories 'increased', 'decreased', 'recov- ered', 'no change', 'tissue loss', and 'dead', based oncomparisons of photographs from the beginning and end of the study. Tumor colonies that later also became infected with PUWS ('newly infected with PUWS') and PUWS colonies later infected with tumors ('newly infected with tumors') were recorded accordingly.

Gradient study: Between March 2003 and April 2003, 15 reef sites were examined along a $41 \mathrm{~km}$ environmental gradient of decreasing human population density approximated by distance from a human population center, Dumaguete City (Fig. 1). Along the gradient, prevalence and severity of tumors on massive Porites and PUWS on all Porites were recorded and analyzed. Sites along the gradient were in a line paralleling the coastline north and south of and centered on the Dumaguete City pier ( $9^{\circ} 18.918^{\prime} \mathrm{N}$ and $\left.123^{\circ} 18.705^{\prime} \mathrm{E}\right)$.

Region-wide study: During April and May 2003, 13 other sites in the region (up to $400 \mathrm{~km}$ from Dumaguete) were also surveyed for disease prevalence and severity (Fig. 1).

Disease incidence study: For the purpose of long-term monitoring of disease incidence and changes in population density and structure, 10 permanent transects with a range of disease prevalence were established by installing metal markers at the start and end of each transect. Transects among the gradient sites, 1 to $3 \mathrm{~km}$ north of the Dumaguete City pier, were utilized for this purpose. They were first surveyed in April 2003 and again in August 2003. Each colony was also measured, but population structure data are not reported here. Water temperatures were recorded between 12:00 and $17.00 \mathrm{~h}$ each day during all the surveys, using a laboratory thermometer made and calibrated by H-B Instruments and tested against thermometer standards traceable to National Institute of Standards and Technology (NIST) with an accuracy of $\pm 1^{\circ}$.

Disease progression and mortality study: In December 2002 and January 2003, near SUML, 35 colonies with PUWS, 68 with tumors and 13 unaffected colonies were tagged, photographed and examined to estimate and record disease severity. The colonies were reexamined weekly to monthly. After an average time span of $8 \mathrm{mo}$, tagged colonies were given a final examination to 
record an estimate of disease severity and progression. Each tagged colony was photographed at least at the start and end periods of the study and at approximately the same angle and distance. Both close-up $(20 \mathrm{~cm})$ and distant $(1 \mathrm{~m})$ photographs were taken. Close-up photos portrayed a small metric ruler, which transected the same diseased area in both the start and end photos. Comparisons of the start and end photos allowed an approximate determination of the disease progression, regression, colony recovery or mortality.

Study species: Because of the difficulty in distinguishing some Porites species in situ (Veron 1995, 2000), and the impracticality of sampling and identifying each colony in the laboratory, species were placed in the category 'massive' or 'branching' species, for analyses. Microscopy confirmed the presence of the large (>1 m diameter) massive species, Porites lutea, $P$. lobata, P. solida, P. mayeri, and P. australiensis. Included in the massive group above were the 'small massive species' (Veron 2000), P. murrayensis, P. stephensoni, and $P$. densa. Because the most common branching species, P. cylindrica, P. attenuata, and P. nigrescens, are similar in situ they were also combined. Thus, the following 'branching' group, which were identified in the lab and were all observed with PUWS, included $P$. cylindrica, $P$. attenuata, $P$. nigrescens, and $P$. annae (a somewhat common and recognizable species). Very rarely or never observed with PUWS were the following more recognizable branching Porites that were not included and not common at transect depths,

Table 1. Porites sp. Disease prevalence among Porites colonies in 27 sites in the Central Philippines. Numbered sites are along a $41 \mathrm{~km}$ human impact gradient. Site 10 is the largest human population center. The other sites are near much smaller towns. Sites 1 to 9 are facing the narrow Tañon Strait and 11 to 15 are facing the open Bohol Sea. The other Tañon Strait sites are further $\mathrm{N}$ and $\mathrm{E}$ of the gradient. Total no. Porites colonies: massive and branching species, both affected by Porites ulcerative white spot disease (PUWS). Only massive Porites were affected by tumors. PUWS severity was based roughly on the number of spots per colony. Tumor severity was the percentage of total surface area affected. tf: too few colonies to average, -: no data. Note that Looc, Negros and Looc, Cebu are 2 different sites

\begin{tabular}{|c|c|c|c|c|c|c|c|}
\hline \multicolumn{2}{|r|}{ Site name } & $\begin{array}{c}\text { Total no. } \\
\text { Porites } \\
\text { colonies }\end{array}$ & $\begin{array}{l}\% \text { infected } \\
\text { with } \\
\text { PUWS }\end{array}$ & $\begin{array}{l}\text { PUWS } \\
\text { severity } \\
\text { (mode) }\end{array}$ & $\begin{array}{c}\text { Total no. } \\
\text { massive } \\
\text { Porites }\end{array}$ & $\begin{array}{l}\% \text { massive } \\
\text { Porites } \\
\text { with tumors }\end{array}$ & $\begin{array}{c}\text { Average } \\
\text { tumor } \\
\text { severity }(\%)\end{array}$ \\
\hline \multicolumn{8}{|c|}{ Sites along $\mathrm{SE}$ Negros Island gradient, $\mathrm{N}$ to $\mathrm{S}$} \\
\hline $1 \quad \mathrm{~L}$ & Lalaan (San Jose) & 466 & 2.4 & Moderate & 380 & 15.3 & 21.8 \\
\hline 2 & Calo River & 124 & 2.4 & Moderate & 122 & 12.3 & 13.8 \\
\hline 3 & Cangmating & 333 & 2.7 & Moderate & 230 & 25.2 & 24.0 \\
\hline 4 & Maslog River & 335 & 1.2 & Moderate & 269 & 23.1 & 27.2 \\
\hline 5 & Calongcalong Pt. & 363 & 18.5 & Moderate & 314 & 32.8 & 33.7 \\
\hline 6 & Agan-an (north) & 582 & 14.3 & Moderate & 432 & 39.1 & 29.1 \\
\hline 7 & Agan-an (south) & 397 & 5.3 & Light & 392 & 38.5 & 33.1 \\
\hline 8 & Airport runway & 322 & 4.7 & Light & 298 & 19.5 & 19.1 \\
\hline 9 & Piapi (Escaño) & 248 & 29.4 & Moderate & 229 & 2.2 & tf \\
\hline 10 & Looc (Dumaguete City pier) & 351 & 43.6 & Moderate & 291 & 6.2 & 22.8 \\
\hline 11 & Mangnao & 252 & 0.0 & tf & 238 & 0.4 & tf \\
\hline 12 & Banilad & 670 & 0.3 & tf & 496 & 4.4 & 11.6 \\
\hline 13 & Poblacion & 954 & 1.8 & Moderate & 328 & 9.2 & 29.2 \\
\hline 14 & Masaplod & 190 & 0.0 & $\mathrm{tf}$ & 110 & 0.9 & tf \\
\hline 15 & Bonbonan & 256 & 0.4 & $\mathrm{tf}$ & 223 & 1.8 & 7.3 \\
\hline \multicolumn{8}{|c|}{$\begin{array}{l}\text { Other Tañon Strait sites, } \mathrm{N} \text { to } \mathrm{S} \\
\text { Sillon Island }\end{array}$} \\
\hline & (off Bantayan Island) & 551 & 0.9 & $\mathrm{tf}$ & 383 & 15.9 & 19.2 \\
\hline & Panagsama (Cebu) & 872 & 0.0 & $\mathrm{tf}$ & 701 & 1.6 & 12.8 \\
\hline & Pescador Island & 611 & 0.2 & $\mathrm{tf}$ & 426 & 0.0 & tf \\
\hline & Calagcalag (Negros) & 301 & 0.0 & tf & 196 & 11.2 & 13.2 \\
\hline & Bato (Cebu) & 351 & 5.7 & Moderate & 325 & 4.9 & 8.6 \\
\hline & Looc (Cebu) & 67 & 53.7 & Moderate & 52 & 3.9 & $\mathrm{tf}$ \\
\hline \multicolumn{8}{|c|}{ Bohol Sea sites } \\
\hline & Sumilon Island & 288 & 11.5 & Moderate & 136 & 0.7 & $\mathrm{tf}$ \\
\hline & Alona, Panglao Island & 311 & 0.6 & tf & 121 & 1.7 & $\mathrm{tf}$ \\
\hline & Tubod, Siquijor Island & 335 & 0.0 & $\mathrm{tf}$ & 222 & 0.9 & $\mathrm{tf}$ \\
\hline \multicolumn{8}{|c|}{ Other Central Philippine sites } \\
\hline & Olango Island, Cebu Strait & 243 & 0.0 & $\mathrm{tf}$ & 225 & 0.0 & $\mathrm{tf}$ \\
\hline & Snake Island, Honda Bay, Palawan (east) & 223 & 0.0 & $\mathrm{tf}$ & 104 & 5.8 & 5.3 \\
\hline & Sabang Bay, Palawan (west) & 149 & 4.0 & - & 149 & 0.0 & - \\
\hline
\end{tabular}




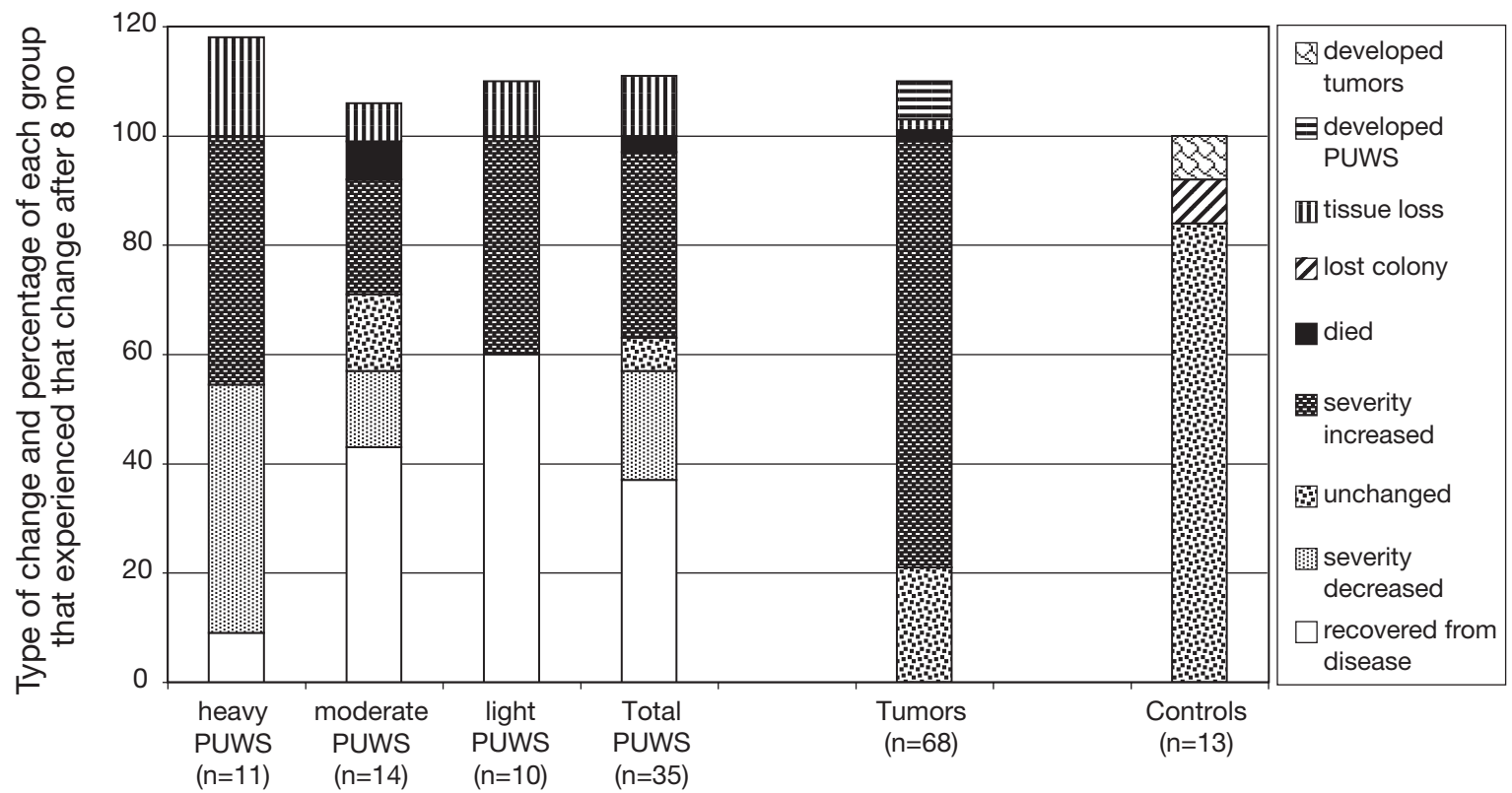

Fig. 2. Porites sp. Bars show the type of changes (e.g. 'increased' in disease severity or 'dead') and the corresponding percentage of each group of tagged colonies (e.g. colonies that were 'moderately infected with Porites ulcerative white spot (PUWS) at the beginning of the monitoring period) that experienced the specific type of change over an average time span of 8 mo. Colonies were grouped as follows at the start of the monitoring period: tagged colonies by PUWS severity; all colonies with tumors; healthy controls. Bars total more than $100 \%$ because of the 'tissue loss' and 'new PUWS/tumors' categories that occurred at the same time as other types of changes

P. vaughani, P. rus, $P$. monticulosa, $P$. horizontalata, $P$. napopora, $P$. sillimaniana, $P$. latistella, $P$. deformis, and $P$. tuberculosa. P. lichen, a somewhat common species, was never observed with PUWS or tumors.

Statistical methods. Spearman's Rank correlation analysis was used in the gradient study to compare disease prevalence to distance from the city center (in this case, the city's downtown pier). The number of paired observations necessary to draw a statistically significant correlation should be between 7 and 30; thus, the choice of 15 sites was appropriate (Fowler et al. 1998). Because observations are proportions (i.e. disease prevalence) and are often not normalized even after transformation, non-parametric analysis was chosen. Chi-square contingency tables were used to test incidence data and the likelihood of recovery based on the relative severity of PUWS infection.

\section{RESULTS}

\section{Field surveys}

The gradient study sites (in the vicinity Dumaguete City, Fig. 1), covered $1720 \mathrm{~m}^{2}$ and within them 5843 colonies were examined, 755 of which had tumors and 458 had PUWS. In 13 isolated sites beyond the gradient, 3930 colonies were examined and of these 117 had tumors and 97 had PUWS. In sites close to Dumaguete City (Fig. 1), epizootic levels of PUWS and Porites tumors were observed. These sites had approximately $40 \%$ prevalence for both diseases (Table 1). In some cases in these sites, tumors were very severe, covering the entire colony surface.

\section{PUWS and tumor progression and mortality}

Comparison of time-series photos of individual colonies revealed a progression of tumor development and/or formation of new tumors on previously unaffected areas for $77.9 \%$ of the affected colonies $(n=68)$; an increase in PUWS severity in $34.3 \%$ of colonies and complete recovery from PUWS in $37.1 \%(n=35$, Fig. 2$)$. Of 11 colonies heavily infected with PUWS 1 recovered completely $(9.1 \%)$, severity decreased in $5(45.5 \%)$, severity increased in $5(45.5 \%)$ and 2 had tissue loss $(18.2 \%)$. Of 10 colonies lightly infected with PUWS 6 recovered completely $(60.0 \%)$. One of the 35 colonies with PUWS died $(2.9 \%)$, 4 had tissue loss (11.4\%) and 13 recovered $(37.1 \%)$. Of these colonies none developed tumors. Out of 68 colonies with tumors, none recovered, tumors remained unchanged in $14(20.6 \%)$, 5 developed PUWS (7.4\%) and 1 died (1.5\%). Five colonies were affected by both tumors and PUWS. Of these, 1 died, the severity of both syndromes increased 


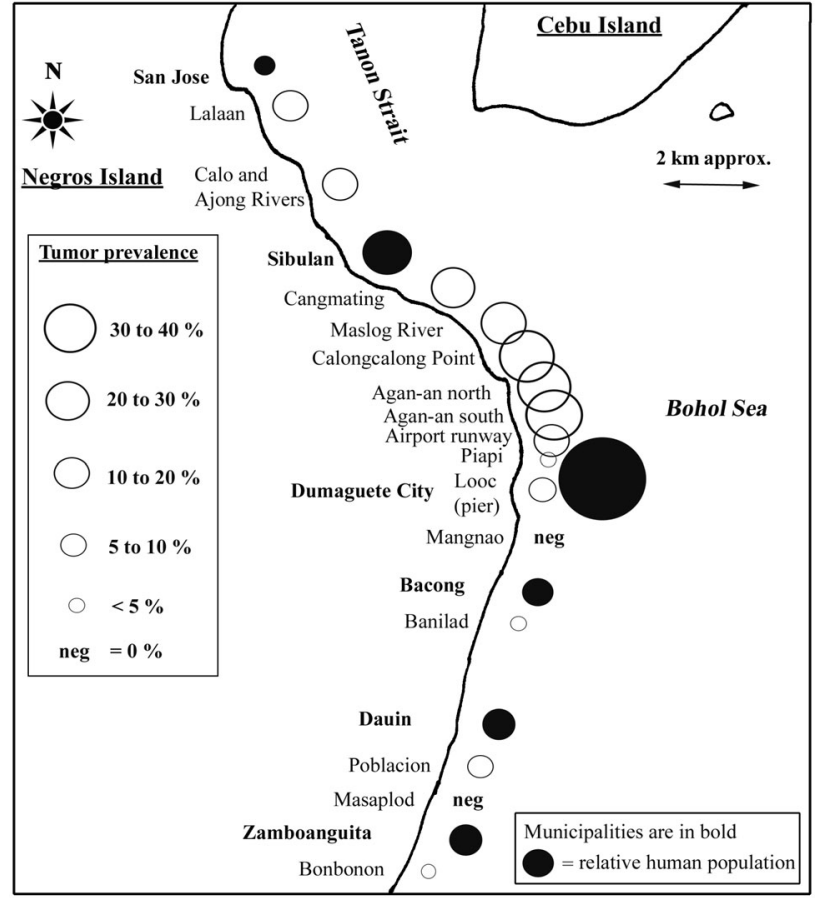

Fig. 3. Porites sp. Tumor prevalence on massive Porites along a $41 \mathrm{~km}$ environmental gradient of increasing distance from an urban center, Dumaguete City, and the corresponding human populations of nearby coastal towns in SE Negros Island, Philippines. For population size, see Fig. 5. The names of the 15 study sites along the gradient are adjacent to the prevalence circles

in 2, PUWS increased and tumors were unchanged in 1 colony, and tumors increased on 1 , but the colony recovered from PUWS. Of the 13 unaffected controls, 1 developed disease (i.e. tumors). Among some tagged colonies, invasion of the central areas of larger tumors by algae, along with focused grazing, appeared to contribute to a progressive necrosis. The mortality rate of the tagged colonies was very low over 8 mo.

\section{PUWS and tumor prevalence along the environmental gradient}

In this study, the environmental or human population gradient fell along reefs extending north and south of Dumaguete City, which is by far the most populated area in Southern Negros. Other towns on the gradient were far smaller (Figs. $3 \& 4$ ). Population figures in Fig. 4 were from the 2000 census and supplied by the Negros Oriental Provincial Planning Office, Dumaguete City. Analysis of coral disease along the gradient (Figs. 1 \& 3) revealed that tumor prevalence and distance from the Dumaguete City pier were modestly negatively correlated (Spearman's rank correlation co-

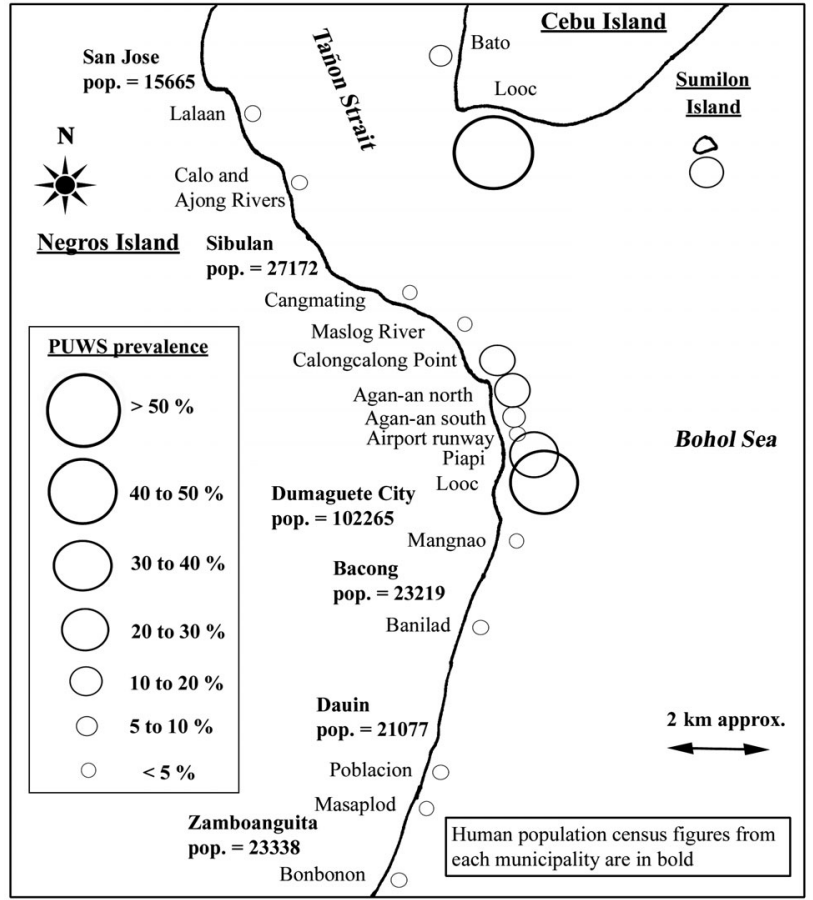

Fig. 4. Porites sp. Prevalence of Porites ulcerative white spot syndrome (PUWS) on branching and massive Porites (combined) along a $41 \mathrm{~km}$ environmental gradient of increasing distance from an urban center, Dumaguete City, southeast Negros, and in 3 sites across the Tañon Strait off southern Cebu Island. Population figures (pop.) of the towns along the gradient are in bold

efficient $\left.\left[\mathrm{r}_{S}\right]=-0.54, \mathrm{p}=0.04\right)$. PUWS prevalence and distance from Dumaguete (Fig. 4) were more strongly negatively correlated $\left(r_{S}=-0.69, p=0.005\right)$. Prevalence was highest in sites near to Dumaguete, tending to attenuate gradually northward along the Tañon Strait sites. South of the Dumaguete, disease prevalence dropped sharply in sites facing the Bohol Sea. The assumption that the diluting effect of the Bohol Sea is responsible for the sharp drop in disease prevalence south of Dumaguete (more or less at the point where the Tañon and Cebu Straits merge into Bohol Sea) and that the city airport runway and pier entrain southbound suspended particles including waterborne pathogens, from the Tañon Strait, were supported by additional analyses described as follows. When only analyzing the 8 northernmost sites (those facing the Tañon Strait) ending at the city airport runway (Fig. 5), correlation for tumors strengthened slightly to $r_{S}=-$ $0.57(p=0.14)$. When the 10 most northern sites ending at the city pier (Fig. 5) were analyzed for PUWS, correlation $\left(r_{S}=-0.80, p=0.005\right)$ increased from a modest to a strong value (Fowler et al. 1998).

Tumor prevalence was strongly correlated with average percent severity $\left(r_{S}=0.71, p=0.004, n=14\right)$. 


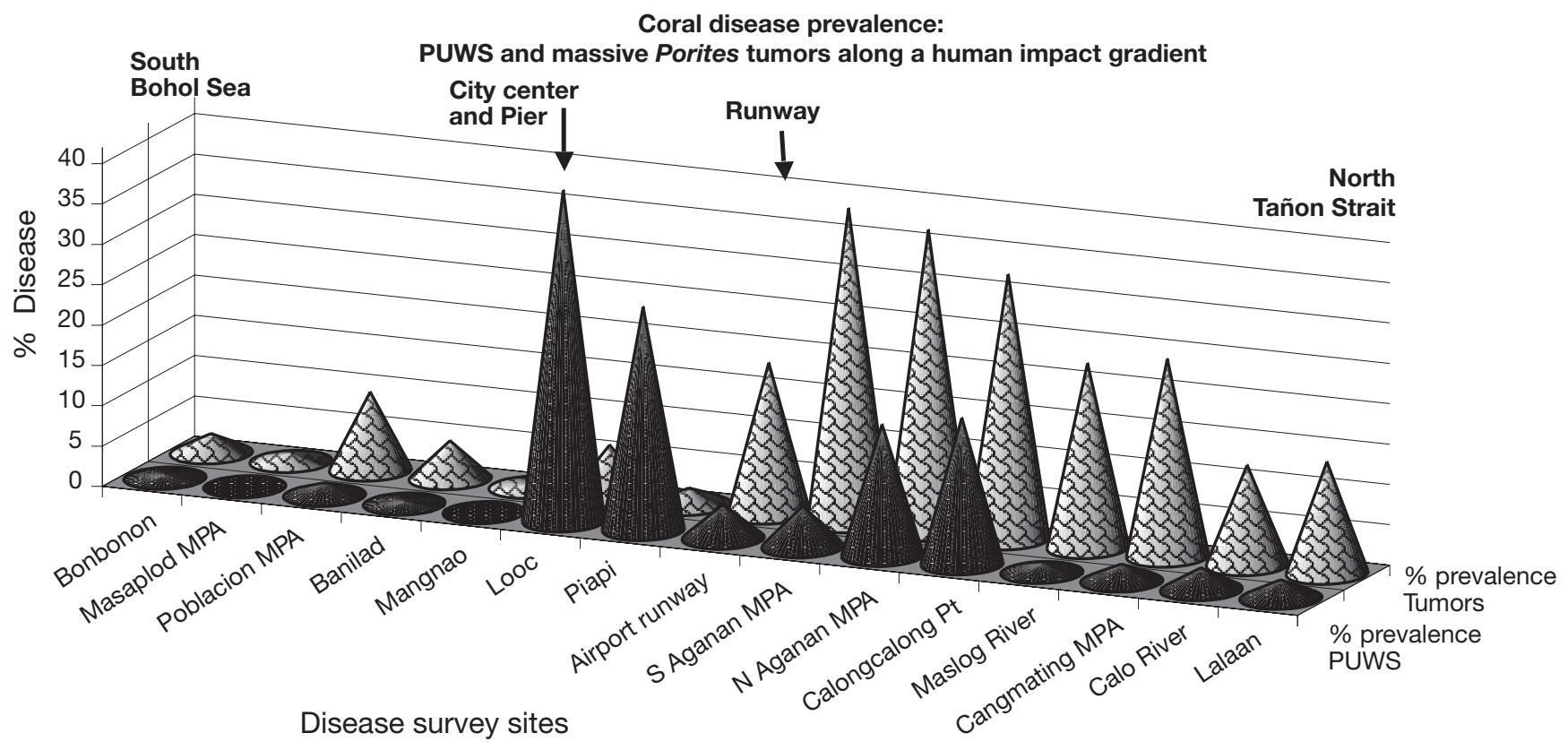

Fig. 5. Porites sp. Comparison of the prevalence of PUWS and tumors along a $41 \mathrm{~km}$ human impact gradient. The primary gradient is centered on an urban center, in this case, the main commercial pier of Dumaguete City (left arrow). Populations of towns to the north and south are markedly smaller. This gradient also transects the restricted waters of the Tañon Strait to the north and the much more open waters of the Bohol Sea to the south (a secondary gradient). Dumaguete lies where these 2 bodies of water meet. The city's airport runway extends seaward $200 \mathrm{~m}$ (right arrow)

PUWS severity also appears correlated with prevalence (Table 1).The first observation of Porites annae with tumors is reported here from the gradient survey.

\section{PUWS and tumor prevalence in other sites}

Beyond the 15 sites within the gradient study, PUWS prevalence was only 0 to $<1 \%$ in the more northern parts of the Tañon Strait, in the Cebu Strait, off islands in the Bohol Sea and off eastern Palawan Island (Table 1 \& Fig. 1). PUWS was highest off the southern tip of Cebu Island (53.7\%) (Table 1 \& Fig. 4). Nearby Sumilon Island had $11.5 \%$ PUWS and western Palawan $4 \%$. Tumor prevalence was higher on the western side and the northern end of the Tañon Strait than elsewhere (Table 1).

\section{Disease incidence}

In August 2003, a resurvey of the 10 permanent transects revealed a significant increase in the number of colonies with PUWS from 62 (of 512 colonies) in March 2003 to 89 (of 503 colonies) in August 2003 ( $p=0.01$ ) and a significant increase in the number with tumors from 75 (of 484) to 97 (of 466) ( $p=0.03$ ). Some smaller colonies may have been lost due to occasional rough sea conditions and/or dislodgement from the high impact fishing activities common in these areas. Water temperatures were warmer in August, as is typical, than March. Sea temperatures in March 2003 ranged from 27.0 to $28.0^{\circ} \mathrm{C}$ and in August from 30.0 to $31.0^{\circ} \mathrm{C}$.

\section{Other diseases and syndromes}

Because so little quantitative data exist for disease prevalence in the Philippines, it is important to report the following limited observations. BBD was infrequent in the region and most often observed near river mouths. Western Palawan had 1 site, near a river, with high prevalence where $7.8 \%$ of a monotypic stand of Montipora aequituberculata $(\mathrm{n}=334)$ was infected with BBD. Porites pink-line syndrome was infrequently observed, mostly near Dumaguete. A white band-like syndrome was observed on a few laminar Montipora colonies off Panglao Island. An undescribed syndrome of massive Porites was seen off Pescador Island where dozens of $4 \mathrm{~cm}$ pale, doughnut-shaped rings surrounding peasized aggregates of mucus and sediment were observed on several colonies. Bleaching was observed, during the warmest period (May to August 2003), in Agan-an off Negros Island, and in Honda Bay off Palawan Island. White band or white plague-like disease was not ob- 
served. Corallivorous sea stars Acanthaster planci and snails Coralliophila neritoidea and the associated recent tissue loss they cause were occasionally observed. Species previously described as susceptible to BBD were also observed infected with BBD in this study, and included Porites lutea, Goniopora sp., and Montipora sp.

\section{Potential new host ranges}

Based on the observation of disease signs identical to those of the PUWS-infected Porites species previously described (Raymundo et al. 2003), potential new host species for PUWS in this study included Echinopora lamellosa, Goniastrea minuta, Heliopora coerulea, Porites annae, Favia stelligera, Favia sp., Montipora grisea, M. malampaya, M. turtlensis, M. digitata, $M$. vietnamensis, and $M$. turgescens. Similarly, potential new hosts of BBD in the Philippines included Coscinaraea columna, E. lamellosa, G. minuta, M. hispida, and $P$. solida, all of which displayed the distinctive black mat in a band between living and recently killed coral.

\section{DISCUSSION}

Porites is a very common, ecologically important group in many shallow Indo-Pacific coral reefs (Veron 1995, 2000). Many Porites are major reef-builders, comprising $30 \%$ of hard coral colonies in reefs in northern and central Philippines (5 to $10 \mathrm{~m}$ depth), and are considered to belong to a hardy, long-lived genus (Raymundo et al. 2004). In 1996, coral cover at a depth of $3 \mathrm{~m}$ on reefs near SUML consisted of up to $65 \%$ Porites (Calumpong et al. 1997). In this study, PUWS was found to affect many species of the genus Porites, both branching and massive, while tumors almost exclusively affected massive species of Porites.

\section{Porites coral tumors}

Of the coral diseases present in the Philippines, PUWS and Porites tumors were predominant during this study. Mortality rates for both were low, and on individual colonies the rate of spread for PUWS was variable and for tumors slow. Tumors were first observed in November 2002, making this the first report of coral tumors in the Philippines. Observations of large massive Porites affected simultaneously by both tumors and PUWS were also a first. Coral tumors, however, have been reported on reefs of most other regions worldwide (Bruckner 2002). According to Veron (2000), neoplasms (or coral tumors) are found in most coral species and considered common. Most descriptions of tumors are for acroporids (Cheney 1975, Bak 1983, Peters 1984, Peters et al. 1986, Uwins et al. 1995, Coles \& Seapy 1998). Tumors in the IndoPacific also affect Platygyra in Australia (Loya et al. 1984), Montipora, Pocillopora and Enallopsammia in Hawaii (Peters et al. 1986), massive Porites in Hawaii (Hunter 1999), Montipora informis in Japan (Yamashiro et al. 2000), Pavona clavus in Costa Rica (Gateño et al. 2003) and Porites lutea, Astreopora myropthalma, and Montipora monasteriata in the Northern Marianas (www.crm.gov.mp). According to Sutherland et al. (2004), there are 24 Indo-Pacific species susceptible to 'skeletal anomalies', a term which includes tumors.

Porites tumors are pale areas of tissue with an inconsistent morphology ranging from round, raised areas of enlarged corallites with distinct demarcation lines between unaffected and diseased tissue to very irregularly shaped depressed areas of white and pink tissue and no distinct lines of separation (Fig. 6A,B ). Unaffected tissues around some tumors appear to grow faster than the tumors themselves, forming a depressed area on the corallum (Fig. 6B). Light microscopy revealed that tumor-associated corallites are enlarged and characterized by thickened corallite walls and deformed skeletal structures (Fig. 6C). Partial mortalities were more common in sites with high prevalence and were possibly the result of tumors, especially if combined with oft-observed focused fish grazing, which is consistent with other studies (Hunter \& Peters 1993, Gateño et al. 2003). Sediments are also more likely trapped on colonies with depressed areas on their upper surfaces, contributing to partial mortalities. Unlike reports describing acroporid tumors, tumor-affected tissues in this study still produced mucus.

Tumors can be quite varied in appearance even in studies involving 1 species (Gateño et al. 2003). Tumors of massive Porites in Hawaii were characterized as anomalous skeletal accretions, resulting in pale, irregularly shaped protuberances with variably enlarged corallites, having distinct lines between unaffected and diseased tissue (Hunter \& Peters 1993, Hunter 1999). Because these tumors notably affect skeletogenesis, they have been described as calicoblastic epitheliomas or skeletal tumors (Peters et al. 1986, Gateño et al. 2003).

There are only a few reports of coral tumors in the Indo-Pacific at the high prevalence values reported here, and none showing such widespread distribution. They involve specific species in very localized sites and include Platygyra pini and P. sinensis in Australia (Loya et al. 1984), Acropora nobilis in Australia (Uwins et al. 1995), Porites lobata in Hawaii (Hunter 1999), 

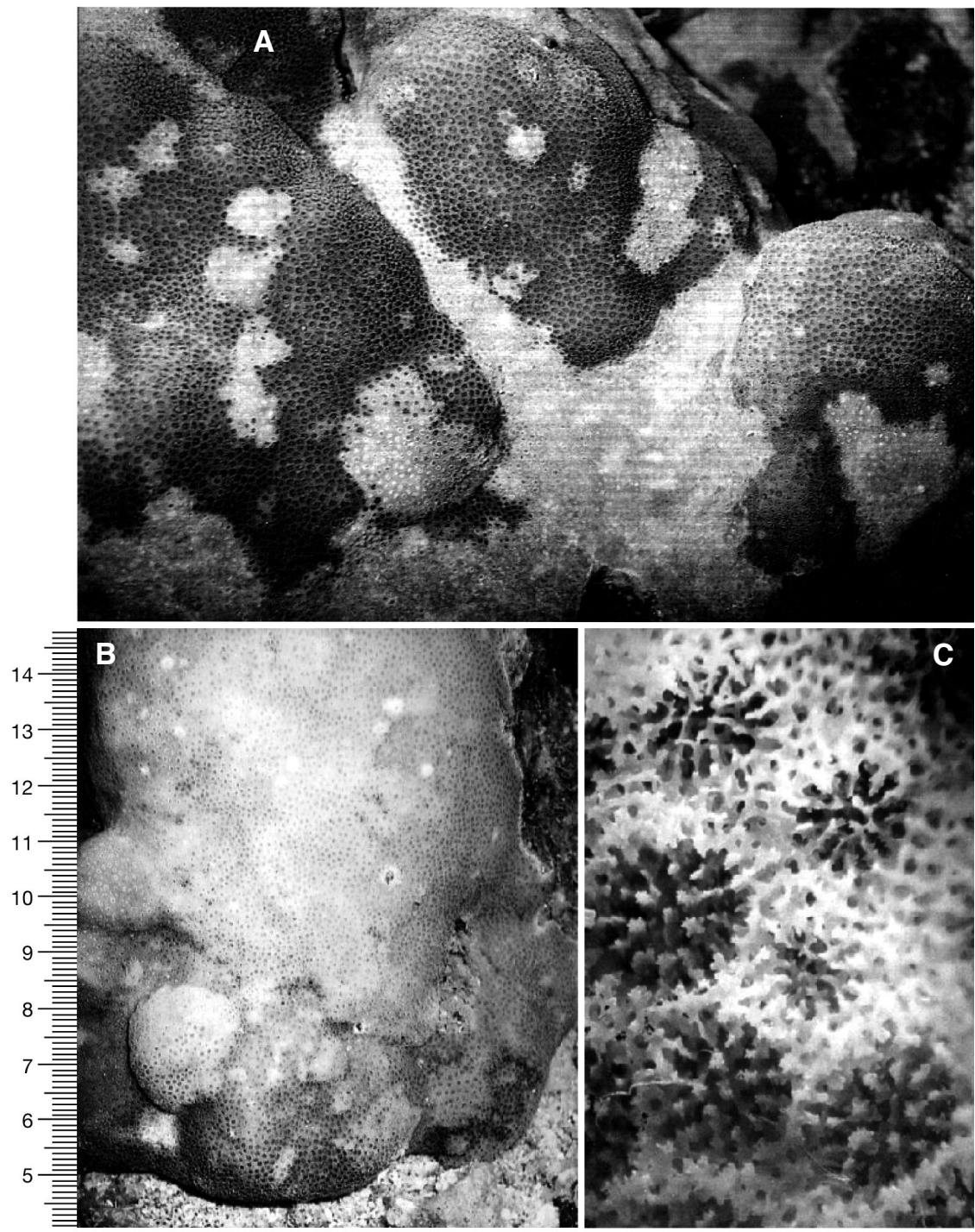

Fig. 6. Porites sp. (A) Typical irregular morphology of Porites tumors with a depressed relief. (B) Porites with over $50 \%$ of the colony affected by tumors with a raised relief. (C) Photomicrograph of the interface between unaffected corallites (lower left) and diseased corallites (upper right). where the corallite walls are clearly thicker and the internal structures deformed

Montipora informis in Japan (Yamashiro et al. 2000) and Pavona clavus in Costa Rica (Gateño et al. 2003).

\section{Porites ulcerative white spot syndrome}

There is relatively little prior research on PUWS as compared to coral tumors. PUWS is characterized by discrete, bleached, round foci, 3 to $5 \mathrm{~mm}$ in diameter, which may result in ulcerations that coalesce and cause tissue loss and colony mortality (Raymundo et al. 2003). A higher incidence of both PUWS and tumors during warmer sea conditions suggests that their virulence increases during these periods. This increase in
PUWS incidence is consistent with earlier research (Raymundo et al. 2003). An increase in sea temperatures during summer months is typical (L. Raymundo and numerous fishers pers. comm.).

\section{Disease progression and mortality}

A large percentage of colonies with PUWS recovered (Fig. 2). While colonies lightly infected with PUWS at the start of the study tended to fully recover (6 out of 10) and those heavily infected did not (1 out of 11), the test for statistical significance failed to support this observation $(p=0.08)$. However, since this was a non-parametric test, a Type II error could have occurred. Frequent recovery suggests that some of these corals may have effective defenses against PUWS infection. In a previous study (Raymundo et al. 2003), mortality and tissue loss from PUWS and disease progression without complete recovery were documented after 25 infected branching Porites attenuata colonies were monitored. Of those colonies, $8 \%$ died, $56 \%$ lost tissue, and tissue was not observed to regenerate once lesions coalesced. In contrast, this study recorded (1) frequent complete recovery after infection, (2) several cases where tissue regenerated after lesions coalesced and tissue was lost, (3) only a few colonies that experienced permanent tissue loss, (4) recovery after infection, then re-infection and, (5) only 1 colony died, and this was infected with both PUWS and tumors. The difference may be due to prevailing environmental conditions, changes in virulence and/or resistance, or a greater hardiness of massive Porites (all the tagged colonies of PUWS-infected branching colonies were lost).

In contrast to PUWS, no colonies with tumors recovered. In most cases, tumor formation slowly progressed suggesting cancer genesis, but in some cases the size remained unchanged. One colony with tumors experienced partial tissue loss and 1 (infected with both diseases) died. Several colonies with tumors developed PUWS but none with PUWS developed tumors. In Hawaii, tumors of massive Porites have been shown to lead to tissue loss and mortality (Hunter 
1999). Of 10 colonies monitored there over 2.5 years, 7 tumors increased in size (5 caused death and 2 caused partial mortality), 2 tumors shrank, with colonies fully recovering, and 1 remained unchanged. In the case of coral tumors, progression to mortality appears to be on the scale of years; however, given the large size of many of the infected colonies whose age is certainly on the scale of decades or more, mortality rates may exceed replacement rates.

\section{Potential new host ranges}

PUWS was originally observed to affect 6 branching species of Porites (P. cylindrica, P. attenuata, P. nigrescens, $P$. annae, $P$. rus and $P$. horizontalata) and unidentified massive Porites (Raymundo et al. 2003). The new observations here more than double the list of potential susceptible species. BBD is typically easy to identify. Thus, the number of new BBD hosts reported here likely increases the current number of species susceptible to BBD in the Indo-Pacific from 45 to 50 (Sutherland et al. 2004). An increase in the potential host range for PUWS that includes several new genera and a new order, suggests a possible increase in virulence (i.e. the pathogen is becoming more abundant) or a lowered resistance of hosts (possibly from environmental degradation or temperature increases). New Philippine hosts of BBD also suggest similar possibilities.

\section{Coral disease and human impact}

Philippine reefs have experienced decades of environmental degradation, especially from sedimentation, pollution, overfishing, and destructive fishing techniques (Burke et al. 2002). General coral reef degradation in the Philippines has been associated with sedimentation from human activities (Gomez et al. 1994). Impacts such as these have been implicated in coral disease outbreaks in other regions of the world (Harvell et al. 1999). Sewage and many industrial wastes are untreated throughout the region and are mostly dumped directly into waterways and the sea. Thus, in coastal cities and towns such as those along the study gradient, the larger the population, the larger the volume of sewage that is directed into the sea. A higher prevalence of coral disease has recently been linked to sewage exposure (Kaczmarsky et al. 2005).

Several review papers and studies have linked anthropogenic influence to coral disease, but only in a hypothetical context (Antonius 1985a, Bruckner et al. 1997, Richardson 1998, Harvell et al. 1999, Al-Moghrabi 2001, Frías-López et al. 2002, Kuta \& Richardson 2002, Patterson et al. 2002, Sutherland et al. 2004). According to Green \& Bruckner (2000), $97 \%$ of studies that recorded coral disease in the Caribbean were from areas considered to have medium to high impacts from human activities. In 2 Caribbean coral diseases, aspergillosis and yellow band, nutrient enrichment has been shown to significantly increase the severity of disease progression (Bruno et al. 2003).

As precise replication of human-impacted field sites is almost impossible, environmental gradient studies may be used to assess quantitative associations between human influence (e.g. population density) and community responses (e.g. disease prevalence) (Hawksworth \& Rose 1976, Gauch 1982, Krebs 1999, Araujo 2003). Correlation analyses in this study linked higher prevalence to population size of coastal cities and towns and possibly to geomorphology and specific man-made obstructions (i.e. the city pier and airport runway extension). Low prevalence at most of the other 13 sites within the region strengthen this conclusion and help link high PUWS prevalence on Sumilon Island to the highly diseased reefs of Dumaguete City, $5 \mathrm{~km}$ away. This link may be due to transmission of pathogens along a cross-shelf front. There was a high prevalence of PUWS in 3 sites directly across the Tañon Strait from Dumaguete, including Sumilon (Fig. 4), yet there was low prevalence or no PUWS observed going further north, east or south of these 3 sites, where human population is also low. This indicates that the cross-shelf connection may be limited in terms of successful waterborne transmission. Waterborne transmission has been previously demonstrated experimentally for PUWS (Raymundo et al. 2003). Porites tumors were most prevalent and severe in sites just north of the Dumaguete airport runway, which extends 200 m seaward (Fig. 3). While the highest prevalence of PUWS was close to this site and just north of the city pier (1 $\mathrm{km}$ south of the airport) and at the southern tip of Cebu, Cebu's closest point to Dumaguete City (Figs. 1, $3 \& 4$, Table 1). The prevalence of PUWS is not depth-related (Raymundo et al. 2003).

\section{Hydrodynamics, disease distribution and prevalence patterns}

When considering the results of the gradient study, tidal activity may limit (i.e. by dilution) the southward spread of disease. Tidal range in southeast Negros, which can be as great as $4 \mathrm{~m}$, is typically $>2 \mathrm{~m}$, twice that of the northern Philippines. Large flood tides come from the south, the direction of the Bohol Sea.

Human activities resulting in large-scale habitat modifications in aquatic habitats can increase the efficiency of transmission of parasites and this can increase parasite virulence (Poulin 1998). The 
Dumaguete city pier and airport runway entrain water and promote retention of sediments, and possibly the pathogens that are contributing to observed diseases. However, at this time, there are no known agents of PUWS or Porites tumors. Sites with the highest prevalence were fairly localized.

Highly virulent pathogens often require only a few cells to cause disease in a host (Madigan et al. 2000). In contrast, with less virulent pathogens, exposure to large numbers of cells of the pathogen may be necessary before a host becomes diseased. Thus, the unnatural entrainment caused by human-created obstructions (i.e. the runway and pier) may be concentrating the numbers of a waterborne pathogen. Since the 1986 Dumaguete airport runway construction, the beach just south of the runway has eroded and the beach north of it has accreted (A. Alcala, previous director of SUML pers. comm.), indicating a net along-shelf sediment transport from the north. The runway and pier are perpendicular to strong tidal, oceanic and winddriven currents, thus they entrain particulates and exacerbate resuspension of silts, which also likely increases a coral colonies level of exposure to pathogens (especially on the north sides). These same attributes also increase coral mucus production and stress. Just north of the runway is the area of highest tumor prevalence and just north of the pier (about $2 \mathrm{~km}$ from the runway) is the area of highest PUWS prevalence on Negros. If these diseases are caused by waterborne pathogens, the entrainment process and resuspension may be involved in disease transmission and the resulting distribution pattern.

Some studies have made limited assessments linking marine disease distribution patterns to water currents. For example, BBD appears to spread downcurrent (Rützler et al. 1983, Antonius 1985b, Bruckner et al. 1997), and aspergillosis of sea fans occurs at higher prevalence in more sheltered areas with less wave action (Nagelkerken et al. 1997). The local aggregation and spread of aspergillosis is likely to be influenced by water currents (Jolles et al. 2002). Similarly, the spread of the suspected epizootic pathogen of the sea urchin Diadema antillarum appeared to follow the predominant currents in the Caribbean basin (Lessios et al. 1984). It has been suggested that of transmission mechanisms that work on a small scale, local hydrodynamics could cause non-random patterns in the dispersion of pathogens (Jolles et al. 2002).

When considering the distribution and prevalence patterns of disease in this study, the most interesting was that they appeared not to be random, but distinctly linked to the environment (Table 1, Figs. 3,4 \& 5). The sites adjacent to the Bohol Sea had little or no disease, while sites facing the Tañon Strait tended to gradually increase from the northernmost sites south to Duma- guete. This led to the conclusion that the occurrence of high prevalence is positively influenced by factors associated with the Tañon Strait and that prevalence increases as one approaches the most geomorphologically constricted point of the Tañon Strait, between Dumaguete City and the southern tip of Cebu (Fig. 1). This constriction contributes to increased disease prevalence possibly by entrainment of pathogens and/or sediments or pollutants that compromise disease resistance. Coastal and benthic geomorphologies can dictate processes of transport of passive particles (Shanks 1995, Carleton et al. 2001, Palumbi 2001, Underwood \& Keough 2001), likely including waterborne pathogens. The dramatic decline in prevalence south of the point where the Bohol Sea meets the Tañon Strait possibly reflects a reduced exposure to pathogens as a result of the flushing and diluting effects of the flood tide.

Another interesting finding was that the fringing reefs of the small, uninhabited island of Sumilon and the nearby tip of Cebu Island, just across the Tañon Strait from Dumaguete City, appear to be influenced by local circulation patterns resulting in high disease prevalence. Initially, the high prevalence of PUWS on uninhabited Sumilon Island would not seem linked to human influence. However, after observing long wrack lines of flotsam between Dumaguete and Sumilon and holding interviews with local fishermen in the course of this study, it became apparent that a crossshelf water current directly between Dumaguete and Sumilon and a distinct front were typical. A seafloor ridge connecting Dumaguete with the southern tip of Cebu, plus the geomorphological constriction between these points (Fig. 1), most certainly influences water flow and facilitates cross-shelf connectivity. In this region, the year is divided by northeast and southwest monsoon wind seasons, which have the same geographic orientation as Dumaguete and Sumilon. Thus, wind also appears to plays a role in cross-shelf connectivity. Wind-driven currents might contribute to onshore transport and steady exchange of waterborne pathogens and, thus, maintenance of high prevalence levels, regardless of direct anthropogenic impact. The observed fronts seem to be formed from an interaction between oceanic and tidal currents where the different bodies of water meet i.e. Tañon Strait and Bohol Sea (see Shanks 1995, Palumbi 2001, Underwood \& Keough 2001). This observed front may act as a mode of transmission for a potential PUWS pathogen between Dumaguete and Sumilon. Tumors appear to be more restricted to the western shore of the Tañon Strait (Table 1).

Massive Porites are prolific producers of mucus and very tolerant of silty areas (Veron 2000). Sheets of Porites mucus were readily identified and most fre- 
quently observed in the often turbulent conditions near the airport runway extension. Coral mucus entraps particulates that could include potential tumorcausing pathogens. Particulates typically aggregate with mucus and soon sink (Mitchell \& Chet 1975, Wild et al. 2004a,b), limiting dispersal potential. Thus, coral mucus may be a vector for potential tumor-causing pathogens, especially along a nearly continuous reef (i.e. the Negros coast) but not as successfully so across open waters between islands (i.e. the Tañon Strait). Disease distribution patterns suggest different dispersal potentials for the potential agents causing these 2 diseases of Porites. Both distribution patterns do not appear to be random and appear somewhat different.

Though preliminary, this is one of only a few studies quantitatively linking coral disease distribution patterns to human population centers and hydrodynamics. The fine spatial scale utilized (i.e. the close proximity of numerous sites) and large sample sizes produced a fine resolution, yielding a statistically significant, non-random and interpretable pattern. It allowed the discernment of a gradual and almost steady decline in disease with increasing distance from an urban center in the northward direction. Though under-utilized in coral disease epizootiology, gradient studies may be valuable tools to assess the role of environment in coral disease dynamics.

\section{CONCLUSION}

Despite high prevalence in a few sites, much lower levels of disease were observed in a majority of the sites and thus this study provides a working baseline from which to investigate causes of future outbreaks. A common complaint of investigators is the lack of quantitative baseline data on normal levels of disease by which to compare apparent outbreaks and to determine if prevalence is indeed higher than normal, especially in the context of recent environmental changes (Harvell et al. 1999). The focus of this study was the genus Porites, but all other diseased corals were recorded. Since only a few colonies among thousands of individuals from hundreds of species were diseased, precise quantification for all species was logistically prohibitive.

PUWS poses a potential threat to Philippine reefs (Raymundo et al. 2003, present study). While recovery from PUWS among massive Porites is common, for some colonies tissue loss and mortality does occur, especially for severely infected colonies and in heavily affected areas. A potential also exists for serious impact to Philippine reefs from tumors on the ecologically important massive Porites because recovery does not seem to occur and it usually worsens. Fortunately, Philippine reefs are not at present being impacted as severely by epizootics as Caribbean reefs, but concern should be raised as the 2 syndromes described here occur in high prevalence in some sites and have potential for long-term impact. Human activity likely plays a role in the high prevalence of the 2 syndromes on reefs of the Philippines, affecting the ecologically important genus Porites.

Acknowledgements. I thank Drs. C. D. Harvell, E. Weil and L. J. Raymundo for suggestions in planning this study; L. L. Richardson, J. Voss and 2 anonymous reviewers for comments on the manuscript; and staff at SUML and S. Kulyk for field and laboratory assistance. Funding and support for this project was from The J. William Fulbright Foreign Scholarship Board, The Philippine-American Educational Foundation, C. W. Post College of Long Island University, Silliman University Marine Laboratory (SUML) and the International Coral Reef Symposium (ICRS) Student Travel Award Program.

\section{LITERATURE CITED}

Al-Moghrabi SM (2001) Unusual black band disease (BBD) outbreak in the northern tip of the Gulf of Aqaba (Jordan). Coral Reefs 19:330-331

Antonius A (1985a) Coral diseases in the Indo-Pacific: a first record. PSZN I: Mar Ecol 6:197-218

Antonius A (1985b) Black band disease infection experiments on hexacorals and octocorals. Proc 5th Int Coral Reef Symp 6:155-160

Araujo MB (2003) The coincidence of people and biodiversity in Europe. Glob Ecol Biogeogr 12:5-12

Bak RPM (1983) Neoplasia, regeneration and growth in the reef-building coral Acropora palmata. Mar Biol 77: 221-227

Bruckner AW (2002) Priorities for effective management of coral diseases. NOAA Tech Memo NMFS-OPR-22, Washington, DC

Bruckner AW, Bruckner RJ, Williams EH (1997) Spread of black band disease epizootic through the coral reef ecosystem in St. Ann's Bay, Jamaica. Bull Mar Sci 61: 919-928

Bruno JF, Petes LE, Harvell CD, Hettinger A (2003) Nutrient enrichment can increase the severity of coral diseases. Ecol Lett 6:1056-1061

Burke L, Selig E, Spalding M (2002) Reefs at risk in Southeast Asia. World Resources Institute, Washington, DC

Calumpong HP, Estacion JS, Lepiten MV, Acedo CE (1997) Status of the coastal resources of the Negros learning site (Manjuyod to Dauin). COE-CRM Document No. 1/97. Silliman University Marine Laboratory, Dumaguete City

Carleton JH, Brinkman R, Doherty PJ (2001) The effects of water flow around coral reefs on the distribution of presettlement fish (Great Barrier Reef, Australia). In: Wolanski E (ed) Oceanographic processes of coral reefs. CRC Press, Boca Raton, FL, p 209-230

Cheney DP (1975) Hard tissue tumors in scleractinian corals. Adv Exp Med Biol 64:77-87

Coles SL, Seapy DG (1998) Ultra-violet absorbing compounds and tumorous growths on acroporid corals from Bandar Khayran, Gulf of Oman, Indian Ocean. Coral Reefs 17: 195-198 
Fowler J, Cohen L, Jarvis P (1998) Practical statistics for field biology, 2nd edn. John Wiley and Sons, New York

Frías-López J, Zerkle AL, Bonheyo GT, Fouke BW (2002) Partitioning of bacterial communities between seawater and healthy, black band diseased, and dead coral surfaces. Appl Environ Microbiol 68:2214-2228

Gateño D, Leon A, Barki Y, Cortes J, Rinkevich B (2003) Skeletal tumor formations in the massive coral Pavona clavus. Mar Ecol Prog Ser 258:97-108

Gauch HG Jr (1982) Multivariate Analysis in community ecology. Cambridge University Press, New York

Gomez ED, Alino PM, Yap HT, Licuanan WRY (1994) A review of the status of Philippine reefs. Mar Pollut Bull 29: $62-68$

Green EP, Bruckner AW (2000) The significance of coral disease epizootiology for coral reef conservation. Biol Conserv 96:347-361

Harvell CD, Kim K, Burkholder JM, Colwell RR and 9 others (1999) Emerging marine diseases-climate links and anthropogenic factors. Science 285:1505-1510

Hawksworth DL, Rose F (1976) Lichens as pollution monitors. Edward Arnold, London

Hunter CL (1999) First records of coral disease and tumors on Hawaiin reefs. In: Maragos JE, Grober-Dunsmore R (eds) Proc Hawaii Coral Reef Mon Workshop. Program on Environment, East-West Center, Honolulu, HI, p 73-97

Hunter CL, Peters EC (1993) Effects of stress-induced necrosis and 'tumors' on the scleractinian coral, Porites lobata, in Hawaii. Am Zool 33:19

Jolles AE, Sullivan P, Alker AP, Harvell CD (2002) Disease transmission of aspergillosis in sea fans: inferring process from spatial pattern. Ecology 83:2373-2378

Kaczmarsky L (2004) Dynamics of coral diseases and syndromes in the central Philippines: prevalence, distribution, progression rates, host ranges, anthropogenic links, and experimental evidence of pathogen involvement in coral neoplasia. Proc 10th Int Coral Reef Symp (Abstract volume) Oral 1-4-B:170

Kaczmarsky L, Draud M, Williams EH (2005) Is there a relationship between proximity to sewage effluent and the prevalence of coral disease? Caribb J Sci 41:124-137

Krebs CJ (1999) Ecological methodology, 2nd edn. AddisonWesley Publishers, Menlo Park, CA

Kuta KG, Richardson LL (2002) Ecological aspects of black band disease of corals: relationships between disease incidence and environmental factors. Coral Reefs 21:393-398

Lessios HA, Robertson DR, Cubit JD (1984) Spread of Diadema mass mortality through the Caribbean. Science 226:335-337

Loya Y, Bull G, Pichon M (1984) Tumor formation in scleractinian corals. Helgol Meeresunters 37:99-112

Madigan MT, Martinko JM, Parker J (2000) Biology of Microorganisms, 9th edn. Prentice-Hall, Upper Saddle River, NJ

Mitchell R, Chet I (1975) Bacterial attack of corals in polluted seawater. Microb Ecol 2:227-233

Nagelkerken I, Buchan K, Smith GW, Bonair K and 10 others (1997) Widespread disease in Caribbean sea fans. II. Patterns of infection and tissue loss. Mar Ecol Prog Ser 160: 255-263

Palumbi SR (2001) The ecology of marine protected areas. In: Bertness MD, Gaines SD, Hay ME (eds) Marine community ecology. Sinauer, Sunderland, MA, p 509-530

Patterson KL, Porter JW, Ritchie KB, Polson SW, Mueller E, Peters E C, Santavy DL, Smith GW (2002) The etiology of white pox, a lethal disease of the Caribbean elkhorn coral, Acropora palmata. Proc Natl Acad Sci USA 99:8725-8730
Peters EC (1984) A survey of cellular reactions to environmental stress and disease in Caribbean scleractinian corals. Helgol Meeresunters 37:113-137

Peters EC, Halas JC, McCarty HB (1986) Calicoblastic neoplasms in Acropora palmata, with a review of reports on anomalies of growth and form in corals. J Natl Cancer Inst 76:895-912

Poulin R (1998) Evolutionary ecology of parasites. Chapman \& Hall, London

Ravindran J, Raghukumar C (2002) Pink line syndrome (PLS) in the scleractinian coral Porites lutea. Coral Reefs 21:252

Raymundo L, Maypa A (2002) Recovery of the Apo Island Marine Reserve, Philippines, 2 years after the El Niño bleaching event. Coral Reefs 21:260-261

Raymundo LJ, Harvell CD, Reynolds TL (2003) Porites ulcerative white spot disease: description, prevalence, and host range of a new coral disease affecting Indo-Pacific reefs. Dis Aquat Org 56:95-104

Raymundo LJ, Reboton CT, Rosell KB, Kaczmarsky LT (2004) Coral diseases and syndromes affecting coral reefs in the Philippines. Proc 10th Int Coral Reef Symp (Abstract volume) Oral 1-4-B:170

Richardson LL (1998) Coral diseases: What is really known? Trends Ecol Evol 13:438-443

Rosenberg E, Loya Y (eds) (2004) Coral health and disease. Springer-Verlag, Berlin

Rützler K, Santavy DL, Antonius A (1983) The black band diseases of Atlantic reef corals. III. Distribution, ecology and development. PSZN I Mar Ecol 4:329-358

Shanks A (1995) Mechanisms of cross-shelf dispersal of larval invertebrates and fish. In: McEdward L (ed) Ecology of marine invertebrate larvae. CRC Press, Boca Raton, FL, p 323-368

Sutherland KP, Porter JW, Torres C (2004) Disease and immunity in Caribbean and Indo-Pacific zooxanthellate corals. Mar Ecol Prog Ser 266:273-302

Underwood AJ, Keough MJ (2001) Supply-side ecology, The nature and consequences of variation in recruitment of intertidal organisms. In: Bertness MD, Gaines SD, Hay ME (eds) Marine community ecology. Sinauer, Sunderland, MA, p 183-200

Uwins PJR, Jones MK, Webb RI, Yago AE, Miller GL, Grinan R, Bell PRF (1995) Determination of the origin and pathology of coral tumors. Marine Environment Conference. Environmental quality, ecology and management in Australasia and Oceania. School of Marine Science, University of Queensland, Brisbane, p 123 (Abstract)

Veron JEN (1995) Corals in space and time. Cornell University Press, Ithaca, NY

Veron JEN (2000) Corals of the World. Australian Institute of Marine Science, Townsville

White AT, Christie P, Divinagracia MF, Apuraado J, Alvarado A, White E (1999) Coral reef surveys for conservation in SW Bohol. Coastal Conservation and Education Foundation, Cebu City

Wild C, Rasheed M, Werner U, Franke U, Johnstone R, Huettel M (2004a) Degradation and mineralization of coral mucus in reef environments. Mar Ecol Prog Ser 267:159-171

Wild C, Huettel M, Klueter A, Kremb S, Rasheed M, Jorgensen B (2004b) Coral mucus functions as an energy carrier and particle trap in the reef ecosystem. Nature 428 : $66-70$

Wilkinson C (ed) (2002) Status of coral reefs of the world: 2002. Australian Institute of Marine Science, Townsville

Yamashiro H, Yamamoto M, van Woesik R (2000) Tumor formation on the coral Montipora informis. Dis Aquat Org 41: 211-217 